\title{
Get Real! @ Your Library-Teen Read Week 2005
}

$\mathbf{W}$ hat is more quintessentially the young adult journey than the search for selfwho am I, where am I headed, what are the possibilities for discovering the individual potential in myself, and creating a meaningful life? And what better map and guide than the right reading experience to make the initial steps on these crucial travels? The month of October each year is prime time for teen reading, as the Young Adult Library Services Association, a division of the American Library Association, celebrates Teen Read Week (October 16$22,2005)$. This year's theme, "Get Real”, with a focus on narrative non-fiction and realistic fiction for young adults, is a natural fit for the voyage of self-discovery. "Teens deserve a wide horizon of books," says author Naomi Shihab Nye. "They read, and the world opens up."

A bit of background on Teen Read Week: begun in 1998 and celebrated the third week in October, this national adolescent literacy initiative is aimed at teens, parents, librarians, educators, booksellers-any and all who care about teenagers and know how essential reading is to healthy, positive development. Teen Read Week encourages young people to "Read for the Fun of It," to make time for leisure reading in their increasingly busy lives. A changing annual subtheme serves as a basis for developing programs in schools, libraries and bookstores to give teen readers the freedom to read something great. Teen Read Week is one of the few active literacy campaigns that focus efforts on teens-giving them time to read just for fun, to select their own leisure reading, and make reading regularly and often a lifetime habit. And one of the most important ways teens acquire a reading habit is by seeing adults they respect read-a lot!

So let's pull together and counteract the statistics from The Nation's Report Card (http://nces.ed.gov/ nationsreportcard) which indicate that in homes across America the number of different types of reading materials has decreased, and a smaller percentage of seventeen year olds saw adults reading in their homes! To learn more, log on to www.ala.org/ teenread, and join Teen Read Week supporters NCTE, the International Reading Association, NEA, the American Booksellers Association, and others to get the message out to teens to "Read for the Fun of It!"

For teen readers whose lives are becoming more real as they find their way into the wider world, suggest journey themes, where an actual trip echoes a metaphorical journey of self-discovery. The journey motif has engaged a variety of writers' imaginations, and crosses a multitude of genres.

In Angela Johnson's Bird, a 13 year old reflects "I thought it was enough that I had to lose two fathers before I'm even a teenager." Determined to hold on to the errant stepfather she loves, Bird follows him south from Ohio to Alabama. Told in the alternating voices of three young people struggling for a way out of loneliness and heartbreaking circumstances, Johnson illuminates their search for simple human connection, and the family ties that make them who they are.

In Paul Fleischman's powerful story of a journey of guilt and restitution, Whirligig, 18 year old Brent seizes the chance to travel far from his old life and 
self, building toys that celebrate the spirit of the young woman whose life he cut short in a drunken driving accident. Along the way, he discovers his own path to reconciliation and growth in the spiral of emotional connections the responses to his whirligigs provoke.

Zack Lane is a biracial teenager frustrated at how little he understands about his own family background (Zack, William Bell) Happily connected to his white father's Jewish relatives, Zack still resents his black mother's refusal to share her family's story. Zack travels from Canada to Mississippi in search of his grandfather, a path that takes him deep into the heart of bigotry, feeling "the full weight of my black skin." Along the way, he learns important truths about his mom's struggles with a father whose hatred of anyone white drove her away from her home, and begins to create for himself a place in two worlds.

Meredith Ann Pierce's marvelous fantasies are steeped in the atmosphere of legend. In Treasure at the Heart of the Tanglewood, we follow Brown Hannah, whose unusual healing powers are valued by a mysterious wizard, for whom she must brew a special potion, and by whom she is forbidden to venture from the heart of the forest. But when love arrives in the form of a handsome young knight, Hannah and her forest companions begin an arduous journey to free her love from evil enchantment, and discover the true nature of her own powers and role of earth mother.

Fans of Lois Lowry's powerful, award-winning The Giver will flock to The Messenger, a novel that brings together characters from that book and Gathering Blue. Young Matty, anxiously awaiting his comingof-age in a naming ceremony, realizes that sinister forces are changing his community from the welcoming, nurturing place it has been. Before the borders of Village are closed for good, Matty undertakes a perilous quest through the dark Forest, hoping to return with Seer's daughter, Kira, whose gift for weaving, along with Matty's own secret powers, may be the only hope to save Village.

Michael Cadnum's Starfall takes the myth of Phaeton and his dangerous journey to the gates of dawn, as the basis for a confrontation between father and son over identity, inherited power and family connection. With the structure of an ancient drama, readers follow young Phaeton from his safe, but too dull home life through his quest to pit his strengths against the dangers of seeking his true father, the mighty sun god Apollo, to the final, devastating choices made by father and son.

Mark Twain's inimicable Huck would find a modern-day soulmate in Chloe Wilder, the heroine of Michael Olshan's Finn. The only way to escape from the violent nightmare of her home life is to stage her own death and flee with her grandparents' maid, Silvia, an illegal immigrant from Mexico. The arduous adventures of their trip to California echo Huck and Jim's voyage of discovery, and reveal that progress and freedom still have a long way to go.

Another young woman fleeing from a violent coming-of-age ritual in an unnamed tropical island world is the heroine of Pat Lowery Collins' The Fattening Hut. Helen instinctively refuses the food that will make her bigger and more beautiful, preparing her for the cutting ceremony and marriage. With the example of her Aunt Margaret to follow, Helen is willing to risk shunning by her village and a dangerous journey through the island's wild forests to give her life other choices.

War and violence are no strangers to 12-year-old Santiago and his sister, Angelina. When soldiers destroy his village and kill his family, Santiago and his sister must flee in a kayak across the Gulf of Mexico to Florida, where their American reception ("stinking boat people") is just another obstacle they must overcome to survive in Ben Mikaelsen's Red Midnight.

A trip to South Africa is not high on Berry Morgan's list of summer plans, but when she accompanies her divorced father to the unveiling of a memorial to her sister, Laura, a church volunteer who was murdered in the struggles following apartheid, there is a chance for healing, forgiveness and hope in Carolyn Coman's Printz honor book Many Stones.

Coming to a new land, a land of hope and dreams of freedom, is the basis of the First Person Fiction series. Edwidge Danticat's Behind the Mountains is the story of 13-year-old Celiane's journey from her beloved home in the mountains of Haiti to join her Papa in the strange world of Brooklyn. Told in lyrical diary entries, Celiane's journey reveals the importance of place in making us who we are.

Difficulties with parents provoke two young men to flee their familiar lives and find a way to envision a future on their own. In Thelma Hatch Wyss' Ten Miles from Winnemucca, Martin's mom's honeymoon trip 
with "Mr. Joe Wonderful” frees him for a journey of his own. Martin and his trusty Jeep travel as far as Red Rock, Idaho, where his money runs out and his burgeoning ingenuity helps him establish himself in a fresh, new way that ultimately gives him a reason to return. Walter Dean Myers gives his young protagonist, Jimmy Little, a painful challenge in Somewhere in the Darkness. From a New York City tenement, Jimmy makes a trip from inner city to his father's rural Southern childhood home with a father he's never known, an escaped convict determined to clear his name and win the love of his son before he dies. The terrible trip mirrors the pain and anger of a desperate father-son quest for connection and understanding, of lessons sought and learned, of dreams won and lost.

Teens can find many wonderful stories that mirror their own adolescent journey to the adults they are becoming. Make Teen Read Week a reading destination for them every October, as we encourage everyone to read for fun, read for the journey.
Mary Arnold is a Regional Teen Services Manager Cuyahoga County Public Library in Ohio. A past YALSA president, Mary currently serves on the ALAN Board of Directors. Mary has contributed articles to YALS, the Young Adult Library Journal, the Continuum Encyclopedia of Young Adult Literature, and Young Adults and Public Libraries: A Handbook of Materials and Services

\section{Books Mentioned:}

Cadnum, Michael. Starfall. Orchard Books, 2004.

Collins, Pat Lowery. The Fattening Hut. Houghton Mifflin, 2003.

Coman, Carolyn. Many Stones. Front Street, 2000.

Danticat, Edwidge. Behind the Mountains. Orchard Books, 2002. Lowry, Lois. The Messenger. Houghton Mifflin, 2004. The Giver. 1993. Gathering Blue. 2000.

Mikaelsen, Ben. Red Midnight. HarperCollins, 2002.

Myers, Walter Dean. Somewhere in the Darkness. Scholastic, 1992.

Olshan, Matthew. Finn. Bancroft Press, 2001.

Pierce, Meredith Ann. Treasure at the Heart of the Tanglewood. Viking, 2001.

Wyss, Thelma Hatch. Ten Miles From Winnemucca. HarperCollins, 2002. 